\title{
Analysis of DNA methylation patterns associated with the gastric cancer genome
}

\author{
YI CHENG $^{1,2}$, ZHI YAN $^{2}$, YIN LIU $^{1}$, CHENGBAI LIANG $^{1}$, HONG XIA $^{1}$, \\ JUNMING FENG ${ }^{3}$, GUORONG ZHENG ${ }^{2}$ and HESHENG LUO ${ }^{1}$ \\ ${ }^{1}$ Department of Gastroenterology, Remin Hospital of Wuhan University, Wuhan, Hubei 430060; \\ Departments of ${ }^{2}$ Gastroenterology and ${ }^{3}$ Pathology, Wuhan General Hospital of Guangzhou Command, \\ Wuhan, Hubei 430070, P.R. China
}

Received June 13, 2013; Accepted December 17, 2013

DOI: $10.3892 / \mathrm{ol} .2014 .1838$

\begin{abstract}
The objective of the current study was to investigate the characteristics of DNA methylation patterns associated with the gastric cancer genome and to identify clinically useful diagnostic markers and therapeutic targets for gastric cancer. The Infinium $450 \mathrm{~K}$ methylation microarray was used to compare differential DNA methylation sites of gastric cancer tissue with that of normal gastric tissue. The results of the DNA microarray analysis were confirmed by pyrosequencing. Functional analysis of the differential genes was performed using the GO software. The effect of candidate site methylation on gene expression was monitored using quantitative polymerase chain reaction analysis. Of the 2,645 differential methylation sites identified in gastric cancer tissues, 2,016 were hypermethylated sites, 629 were hypomethylated sites, 826 were located in promoter regions and 1,024 were located within genes. These differential sites were associated with 1,352 genes. In total, five sites were selected and pyrosequencing verified the results of the microarray analysis in five of the sites. Change in gastric cancer DNA methylation pattern was a common occurrence. Differential methylation sites appeared more often in non-promoter regions. The associated genes were involved in multiple signaling pathways, and hypermethylated and hypomethylated sites were involved in roughly the same signaling pathways. Methylation of the genome promoted gene expression. TRIM15, ITGAM, MSX2 and FAM38A may be candidate genes for diagnosing gastric cancer.
\end{abstract}

\section{Introduction}

Gastric cancer is a malignant disease with high incidence and mortality rates, particularly in Asian populations $(1,2)$. The oncogenesis and development of gastric cancer are influenced

Correspondence to: Professor Hesheng Luo, Department of Gastroenterology, Remin Hospital of Wuhan University, 99 Zhangzhidong Road, Wuhan, Hubei 430060, P.R. China E-mail: droid2013@163.com

Key words: gastric cancer, DNA methylation, genome-wide, methylation microarray by genetic and epigenetic factors. DNA methylation is the most studied epigenetic mechanism. At present, the focus of the majority of studies is the inactivation of gene expression by hypermethylation of DNA located in tumor suppressor gene promoter regions. The observation that promoter CG island methylation inactivates a number of tumor suppressor genes in gastric cancer, such as RASSF1A, P16 and E-cadherin, has increased the understanding of the mechanism of gastric carcinogenesis (3). For technical reasons, the majority of previous studies have focused on only a few genes. With the development of sequencing and microarray technology, a large-scale study of the pattern of DNA methylation, which is also called the methylome, became possible $(4,5)$. The present study analyzed DNA methylation characteristics of the gastric cancer genome using the Infinium $450 \mathrm{~K}$ methylation microarray to further understand the pathogenesis of gastric cancer and identify potential therapeutic targets and diagnostic markers for gastric cancer.

\section{Materials and methods}

Clinical samples. In total, 40 patients with gastric cancer from the Wuhan General Hospital of the Guangzhou Command (Wuhan, China) during the period between March 2011 and June 2012 were included. Each tumor sample was matched with adjacent apparently normal mucosa $(3-5 \mathrm{~cm}$ from the tumor margin) removed during the same surgery. All samples were collected by one surgical pathology fellow from the operating room immediately following the surgical resection and frozen in the liquid nitrogen. Pathological diagnosis was determined independently by two pathologists and disagreement was resolved by consensus. The study protocol was approved by the ethics committee of Wuhan General Hospita 1 of Guangzhou Command (Wuhan, China).

Genomic DNA extraction and quality control. DNA was extracted from $\sim 25 \mathrm{mg}$ of tissue using a DNA extraction kit (Quick-gDNA MiniPrep; Zymo Research Corporation, Orange, CA, USA) according to the manufacturer's instructions, and DNA quality was assessed using spectrophotometry (UV-100, Shanghai Precision Instrument Co., Ltd., Shanghai, China) and agarose gel electrophoresis (Amresco LLC, Solon, OH, USA). 
Table I. Primers for bisulfite pyrosequencing.

\begin{tabular}{|c|c|c|c|c|}
\hline Gene & Sequence & $\mathrm{Nt}$ & $\mathrm{Tm},{ }^{\circ} \mathrm{C}$ & $\mathrm{GC}, \%$ \\
\hline \multirow[t]{3}{*}{ TRIM15 } & F: GGTTTAATGGTAGGTTGTTTAAGT & 24 & 58.4 & 33.3 \\
\hline & R: ATATACCTCACTAАCTTCCTATCTT & 25 & 58.2 & 32.0 \\
\hline & S: ATCCAAAATAATAACCCCT & 9 & 45.2 & 31.6 \\
\hline \multirow[t]{3}{*}{ ITGAM } & F: GTTAAGTGTGGTTTGGGTAGAGTTT & 25 & 59.1 & 40.0 \\
\hline & R: АСТАСТАТСССТСТСАСТАСССТССТСТА & 29 & 60.3 & 48.3 \\
\hline & s: GGGGATTTTTTTTATTTATTATGTT & 25 & 45.0 & 20.0 \\
\hline \multirow[t]{3}{*}{ SLMO2 } & F: GGGGATGAGTTAGGAAGAAGAGT & 23 & 62.6 & 47.8 \\
\hline & R: AATCCCATTCATCACTAATCCATTTCAACT & 30 & 58.9 & 33.3 \\
\hline & S: AGATAGTTTTAGGGAGATTG & 20 & 46.3 & 35.0 \\
\hline \multirow[t]{3}{*}{ MSX2 } & F: GTTTTTAATAGGGTGGAGAGAGATTG & 26 & 60.3 & 38.5 \\
\hline & R: TACCCCCTAATTTCCCACC & 19 & 58.4 & 52.6 \\
\hline & S: ATGGTTTTGTTTTGTTAATAAAAT & 24 & 44.2 & 16.7 \\
\hline \multirow[t]{3}{*}{ FAM38A } & F: TGGGGTTTTTTGATTGTAAAAGT & 23 & 58.3 & 30.4 \\
\hline & R: CTAAАAААТСТТССССАААТТTCАСC & 26 & 60.6 & 34.6 \\
\hline & S: GTTTGTTTGAGGTTTTTAGATA & 22 & 44.1 & 27.3 \\
\hline
\end{tabular}

F, forward; R, reverse; S, sequence to analyze; Nt, nucleotides; Tm, temperature; GC, gastric cancer.

Table II. Primers for quantitative polymerase chain reaction.

\begin{tabular}{lllr}
\hline Gene & \multicolumn{1}{c}{ Forward primer } & \multicolumn{1}{c}{ Reverse primer } & Product, bp \\
\hline Actin & GTCCACCGCAAATGCTTCTA & TGCTGTCACCTTCACCGTTC & 190 \\
TRIM15 & AGCAAGAAGCATCAGGTGGA & GACAAGGTCAGGAGAAATGGC & 294 \\
ITGAM & CCTTGTGGTTCCTCAGTGGT & CTTGGAAGGTCATTGCGTTT & 154 \\
MSX2 & AAGATGGAGCGGCGTGGAT & CGAGGAGCTGGGATGTGGT & 138 \\
FAM38A & ATCCACTCCGGGGACTACTT & GGTAGCTGTCCTGCCTGTTC & 197 \\
\hline
\end{tabular}

bp, base pairs; Tm, temperature.

A

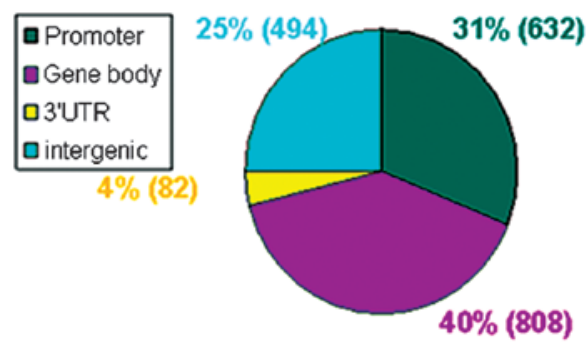

C

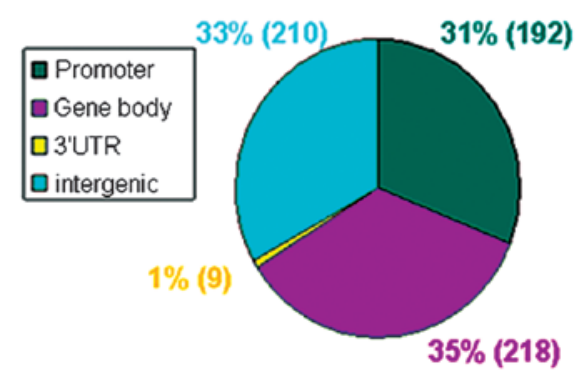

B

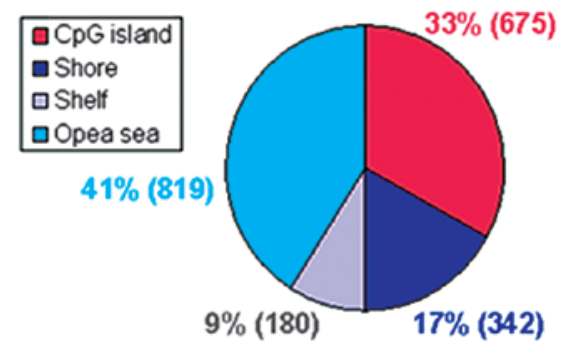

D

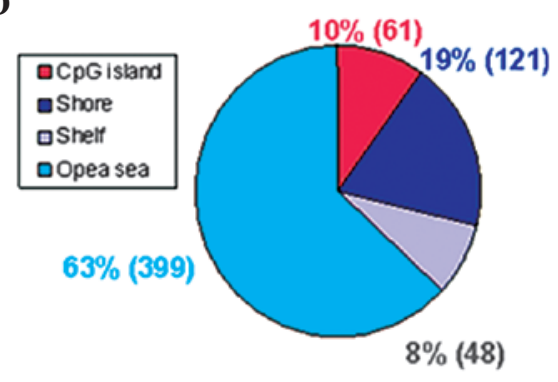

Figure 1. Distribution of the differential methylation sites. (A) Hypermethylated sites were classified into the following functional genomic groups: Promoter, gene body, 3' untranslated region and intergenic. (B) Hypermethylated sites were classified in terms of CpG content, as follows: Island, shore, shelf and 'open sea'. (C) Hypomethylated sites classified into functional genomic groups and (D) hypomethylated sites classified by CpG content. 
Table III. Hypermethylated and hypomethylated sites (partly).

A, Hypermethylated

\begin{tabular}{|c|c|c|c|}
\hline $\begin{array}{l}\text { Target } \\
\text { ID }\end{array}$ & $\begin{array}{l}\text { UCSC } \\
\text { name }\end{array}$ & $\begin{array}{c}\text { UCSC } \\
\text { refGene group }\end{array}$ & Chromosome \\
\hline $\operatorname{cg} 08977390$ & TRIM15 & Body & 6 \\
\hline $\operatorname{cg} 21678445$ & ZNF521 & Body & 18 \\
\hline $\operatorname{cg} 02256631$ & ITGAM & Body & 16 \\
\hline $\operatorname{cg} 01192077$ & EBF1 & Body & 5 \\
\hline $\operatorname{cg} 18369516$ & ZBTB46 & Body & 20 \\
\hline $\operatorname{cg} 06445348$ & ILDR2 & Body & 1 \\
\hline $\operatorname{cg} 18125573$ & RARA & Body & 17 \\
\hline $\operatorname{cg} 04407470$ & NR2E1 & Body & 6 \\
\hline $\operatorname{cg} 22388634$ & VSX1 & Body & 20 \\
\hline $\operatorname{cg} 14063008$ & DAB2IP & Body & 9 \\
\hline $\operatorname{cg} 24171907$ & CNRIP1 & 5'UTR & 2 \\
\hline $\operatorname{cg} 16306190$ & LRRC34 & 1st exon & 3 \\
\hline $\operatorname{cg} 11595545$ & KCNA3 & 1st exon & 1 \\
\hline $\operatorname{cg} 08048222$ & ZNF671 & TSS200 & 19 \\
\hline cg09734791 & MSC & 1st exon & 8 \\
\hline $\operatorname{cg} 25024074$ & ITGA4 & 1st exon & 2 \\
\hline $\operatorname{cg} 16964348$ & NPY & TSS200 & 7 \\
\hline $\operatorname{cg} 17508991$ & $\mathrm{HCK}$ & TSS1500 & 20 \\
\hline $\operatorname{cg} 18372896$ & JDP2 & 5'UTR & 14 \\
\hline $\operatorname{cg} 17219660$ & GPR37L1 & TSS200 & 1 \\
\hline
\end{tabular}

B, Hypomethylated

\begin{tabular}{|c|c|c|c|}
\hline $\begin{array}{l}\text { Target } \\
\text { ID }\end{array}$ & $\begin{array}{l}\text { UCSC } \\
\text { name }\end{array}$ & $\begin{array}{c}\text { UCSC } \\
\text { refGene group }\end{array}$ & Chromosome \\
\hline cg20726575 & SLMO2 & Body & 20 \\
\hline $\operatorname{cg} 06013117$ & MSX2 & Body & 5 \\
\hline $\operatorname{cg} 06007201$ & FAM38A & Body & 16 \\
\hline $\operatorname{cg} 21499869$ & ELL & Body & 19 \\
\hline $\operatorname{cg} 16499677$ & C14ORF37 & Body & 14 \\
\hline $\operatorname{cg} 23263641$ & CADM4 & Body & 19 \\
\hline $\operatorname{cg} 18847089$ & PRKAR1B & Body & 7 \\
\hline cg27341866 & C19orf35 & Body & 19 \\
\hline $\operatorname{cg} 13826564$ & LTBP3 & Body & 11 \\
\hline $\operatorname{cg} 04529865$ & GALNT9 & Body & 12 \\
\hline $\operatorname{cg} 01515802$ & LATR1 & TSS200 & 19 \\
\hline $\operatorname{cg} 22888958$ & CREB5 & 5'UTR & 7 \\
\hline $\operatorname{cg} 23264429$ & STAMBPL1 & 5'UTR & 10 \\
\hline $\operatorname{cg} 19060371$ & LCP1 & 5'UTR & 13 \\
\hline $\operatorname{cg} 01318557$ & LAT2 & 5'UTR & 7 \\
\hline cg22274117 & ATXN1 & 5'UTR & 6 \\
\hline cg06442489 & ZSCAN18 & TSS1500 & 19 \\
\hline cg02829601 & SYTL3 & TSS200 & 6 \\
\hline cg06523556 & CHRNA6 & TSS200 & 8 \\
\hline cg20117742 & LAIR1 & TSS200 & 19 \\
\hline
\end{tabular}

UTR, untranslated region.

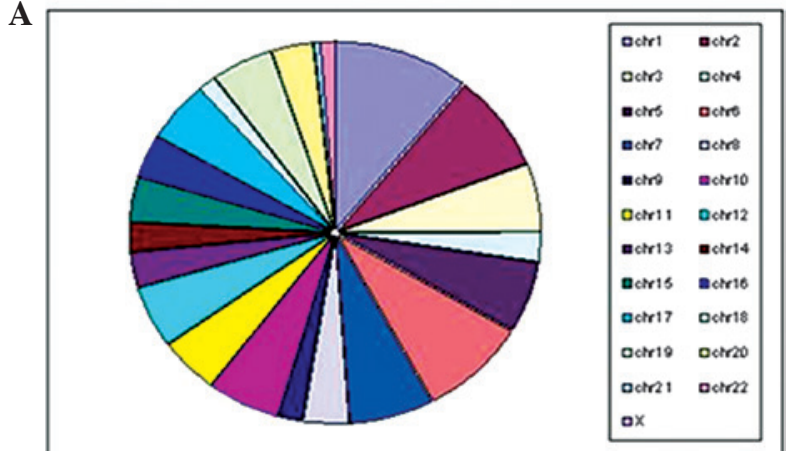

\begin{tabular}{|c|c|c|c|}
\hline Chromosome & CpGs & Chromosome & CpGs \\
\hline Chr1 & 218 & Chr13 & 56 \\
\hline Chr2 & 171 & Chr14 & 53 \\
\hline Chr3 & 115 & Chr15 & 74 \\
\hline Chr4 & 50 & Chr16 & 72 \\
\hline Chr5 & 128 & Chr17 & 108 \\
\hline Chr6 & 173 & Chr18 & 29 \\
\hline Chr7 & 136 & Chr19 & 99 \\
\hline Chr8 & 70 & Chr20 & 68 \\
\hline Chr9 & 41 & Chr21 & 12 \\
\hline Chr10 & 115 & Chr22 & 20 \\
\hline Chr11 & 96 & ChrX & 3 \\
\hline Chr12 & 109 & & \\
\hline
\end{tabular}

B
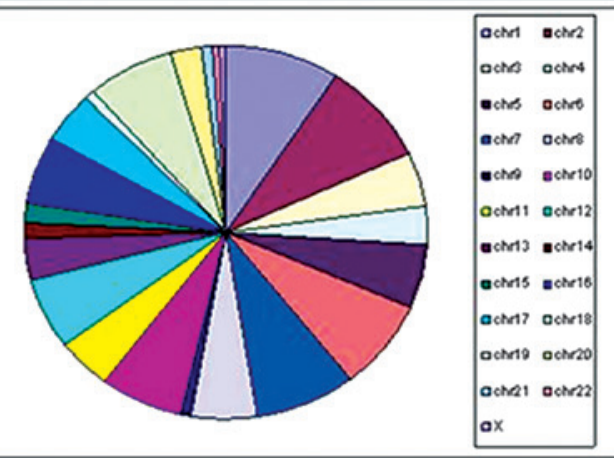

\begin{tabular}{|c|c|c|c|}
\hline Chromosome & CpGs & Chromosome & CpGs \\
\hline Chr1 & 57 & Chr13 & 24 \\
\hline Chr2 & 56 & Chr14 & 8 \\
\hline Chr3 & 31 & Chr15 & 11 \\
\hline Chr4 & 20 & Chr16 & 36 \\
\hline Chr5 & 36 & Chr17 & 29 \\
\hline Chr6 & 48 & Chr18 & 5 \\
\hline Chr7 & 51 & Chr19 & 44 \\
\hline Chr8 & 33 & Chr20 & 15 \\
\hline Chr1 & 5 & Chr21 & 5 \\
\hline Chr10 & 42 & Chr22 & 4 \\
\hline Chr11 & 27 & ChrX & 4 \\
\hline Chr12 & 38 & & \\
\hline
\end{tabular}

Figure 2. Chromosome locations of the differential methylation sites. (A) Hypermethylated and (B) hypomethylated sites.

DNA methylation profiling with Infinium $450 \mathrm{~K}$ methylation assay. In total, six paired samples were processed on the chip (12 samples/chip). Genomic DNA (500 ng) was treated with sodium bisulfite using the Zymo EZ DNA Methylation $\mathrm{Kit}^{\mathrm{TM}}$ (Zymo Research Corporation) according to the manufacturer's instructions, with the alternative incubation conditions recommended for the Illumina Infinium $450 \mathrm{~K}$ methylation assay (Illumina Inc., San Diego, CA, USA). The methylation assay was 
Table IV. Signaling pathway analyses.

\begin{tabular}{|c|c|c|c|c|}
\hline Pathway & Upregulated & P-value & Downregulated & P-value \\
\hline Apoptosis & $\begin{array}{l}\text { BCL2, CAPN2, ENDOD1, } \\
\text { NFKBIA, NTRK1 and PRKACB }\end{array}$ & $9.77 \mathrm{E}-04$ & $\begin{array}{l}\text { CASP8, IL1A, IL1B, } \\
\text { PRKACA and TNFRSF10A }\end{array}$ & 4.44E-05 \\
\hline Cell cycle & ANAPC5, CDH1 and MYT1 & 0.193209 & $\mathrm{CDC} 2, \mathrm{CDK} 1$ and LAT & 0.094077 \\
\hline ErbB & CAMK2B, GAB1, GRB2 and NRG2 & 0.02511 & PRKACA and STAT5A & 0.054748 \\
\hline Jak-STAT & $\begin{array}{l}\text { CNTFR, CSF3R, GHR, GRB2, } \\
\text { IFNK, IL22RA1, IL2RA, IL7 and PIAS4 }\end{array}$ & $1.77 \mathrm{E}-04$ & $\begin{array}{l}\text { IL12B, IL21R, SOCS2, } \\
\text { SOCS5 and STAT5A }\end{array}$ & $5.93 \mathrm{E}-04$ \\
\hline MAPK & $\begin{array}{l}\text { CACNA2D2, CACNA2D3, DUSP16, } \\
\text { FGF12, GNG12, GRB2, MAPKAPK2, } \\
\text { MRAS, NTRK1, PDGFA, PRKACB and } \\
\text { RASGRF1 }\end{array}$ & $2.37 \mathrm{E}-04$ & $\begin{array}{l}\text { CACNA1C, CACNA1H, } \\
\text { CACNA1I, DUSP14, HSPA1A, } \\
\text { HSPA1A, IL1A, IL1B, IL1R2, } \\
\text { MEF2C, NF1, PRKACA, } \\
\text { PRKACA, RPS6KA2 and SCT }\end{array}$ & $1.52 \mathrm{E}-12$ \\
\hline $\mathrm{p} 53$ & SESN1, SESN3 and TSC2 & 0.057786 & CASP8, CDC2, CDK1 and RRM2 & 0.00338 \\
\hline TGF- $\beta$ & $\begin{array}{l}\text { BMP2, CHRD, GDF6, SMAD6, } \\
\text { SMAD7, SMAD9 and SMURF2 }\end{array}$ & $1.25 \mathrm{E}-04$ & BMPR1B and INHBA & 0.054748 \\
\hline Toll-like receptor & NFKBIA, TOLLIP and TRAF3 & 0.140739 & CASP8, IL12B, IL1B and TLR6 & 0.001034 \\
\hline VEGF & MAPKAPK2 and NFATC1 & 0.251502 & NFATC1 and PRKACA & 0.043002 \\
\hline Wnt & $\begin{array}{l}\text { CAMK2B, CTBP2, LRP5, NFATC1, } \\
\text { POR, PPP2R5C, PRICKLE1, PRKACE, }\end{array}$ & $8.63 \mathrm{E}-08$ & $\begin{array}{l}\text { APC, NFATC1, PRKACA and } \\
\text { PRKACA }\end{array}$ & 0.004401 \\
\hline
\end{tabular}

Jak-STAT, Janus kinase-signal transducer and activator of transcription; MAPK, mitogen-activated protein kinases; TGF- $\beta$, transforming growth factor- $\beta$; VEGF, vascular endothelial growth factor.

performed on $4 \mu \mathrm{l}$ of bisulfite-converted genomic DNA at $50 \mathrm{ng} / \mu \mathrm{l}$ according to the Infinium HD methylation assay (Illumina Inc.) instructions. The quality of the results was assessed using the GenomeStudio $^{\mathrm{TM}}$ Methylation Module v1.8 software (Illumina, Inc., San Diego, CA, USA) and all samples passed this quality control. $\beta$-values were extracted using the same software.

Bisulfite pyrosequencing. A total of six CpGs sites were selected for technical validation of Infinium $450 \mathrm{~K}$ methylation by the bisulfate pyrosequencing technique on 40 paired samples (cancer and normal tissues). One candidate site in each of the five genes (TRIM15, ITGAM, SLMO2, MSX2 and FAM38A) was selected and all were located in the gene body. Primers for polymerase chain reaction (PCR) amplification and sequencing were deduced using the PyroMark Assay Design 2.0 software (Qiagen, Hilden, Germany) and all primer sequences are shown in Table I. Bisulfite conversion of genomic DNA was performed, followed by PCR. PCRs were performed under the following conditions: $95^{\circ} \mathrm{C}$ for $15 \mathrm{~min} ; 45$ cycles of $94^{\circ} \mathrm{C}$ for $30 \mathrm{sec}, 56^{\circ} \mathrm{C}$ for $30 \mathrm{sec}, 72^{\circ} \mathrm{C}$ for $30 \mathrm{sec}$; and $72^{\circ} \mathrm{C}$ for $10 \mathrm{~min}$. The success of amplification was assessed by agarose gel electrophoresis and pyrosequencing of the PCR products was performed using the PyromarkID system (Qiagen). Only blue values (perfect calls) were considered for subsequent analyses.

RNA extraction and quantitative PCR ( $q P C R)$. Total cellular RNA was extracted using the TRIzol method. RNA quality was assessed by spectrophotometry and agarose gel electrophoresis. A total of $5 \mu \mathrm{g}$ of RNA was reverse transcribed using the All-in-One ${ }^{\mathrm{TM}}$ First Strand cDNA synthesis kit (AORT-100;
GeneCopoeia $^{\mathrm{TM}}$, Rockville, MD, USA). Quantitative qPCR amplification reactions were performed using the All-in-One qPCR master mix (AOPR-1200; GeneCopoeia) with a Real-Time PCR system (ABI StepOne plus; Applied Biosystems, Carlsbad, CA, USA). The expression levels of the genes were normalized to the expression of actin. Primer sequences and PCR conditions are shown in Table II.

Bioinformatics analysis. Integrated gene ontology and pathway analysis database MAS3.0 (http://www.capitalbio.com) were to investigate potential molecular function and the pathway of the candidate biomarkers.

Statistical analysis. All statistical analyses were performed using SPSS 13.0 for Windows (SPSS, Inc., Chicago, IL, USA). Group comparisons were performed using a paired samples t-test. Two-sided $\mathrm{P}<0.05$ was considered to indicate a statistically significant difference.

\section{Results}

Patients. The present study was conducted on 40 patients (23 male and 17 female) with gastric cancer, with a mean age of 56 years. The methylation microarray procedure was performed on specimens from six patients. The tumors were all adenocarcinomas.

Pyrosequencing. Pyrosequencing was performed on specimens from 40 patients. In total, 2,645 methylation differential sites (covering 1,352 genes) were detected in the gastric cancer 

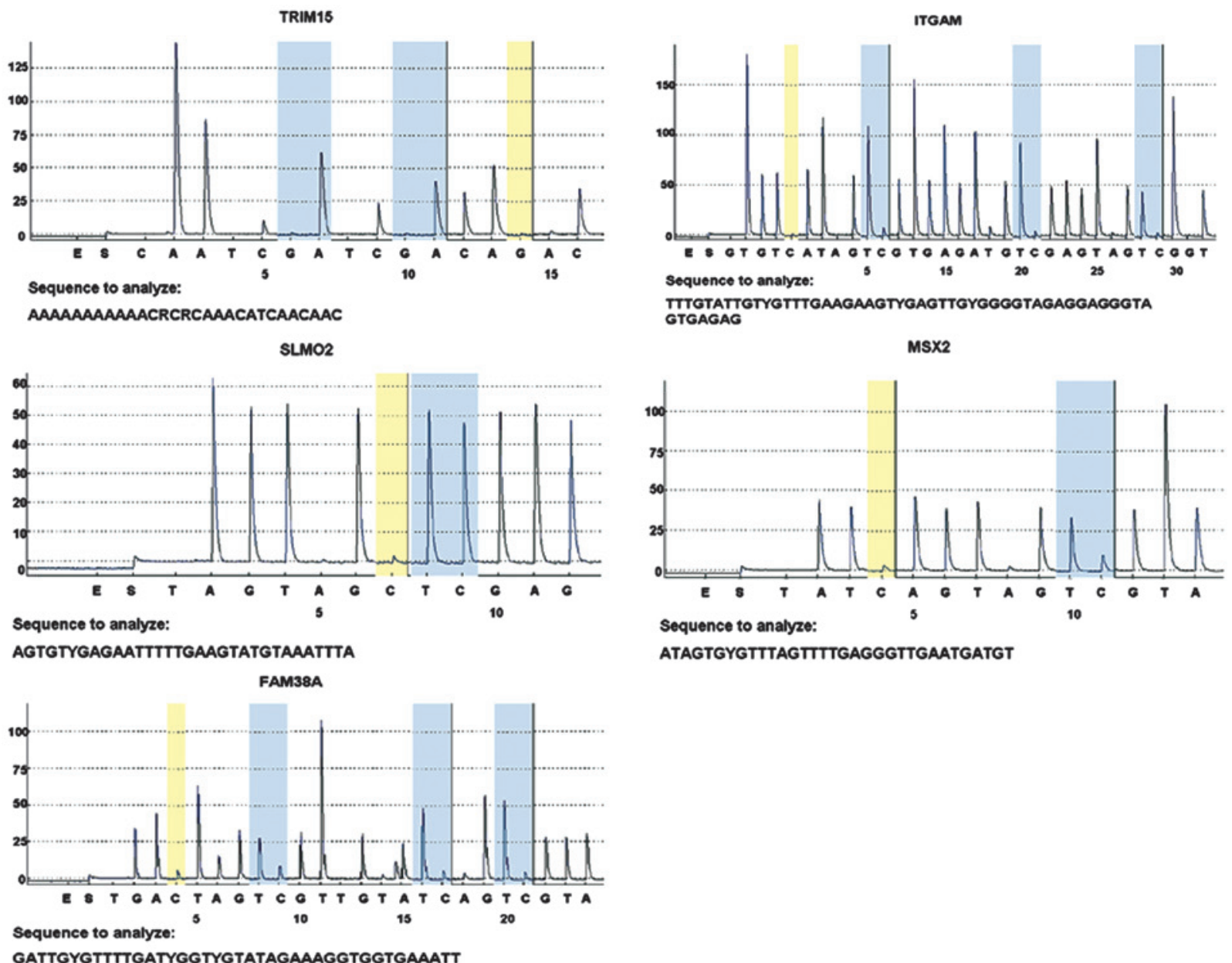

ATAGTGYGTTTAGTTTTGAGGGTTGAATGATGT

Figure 3. Pyrosequencing for five sites.

Table V. Level of methylation of five sites.

\begin{tabular}{llcc}
\hline & \multicolumn{2}{c}{ Level of methylation, $\%$} & \\
\cline { 2 - 3 } Gene & GC tissues & Normal tissues & P-value \\
\hline TRIM15 & $10.71 \pm 3.08$ & $5.86 \pm 1.65$ & $<0.0001$ \\
ITGAM & $44.23 \pm 17.68$ & $26.34 \pm 9.41$ & $<0.0001$ \\
SLMO2 & $74.72 \pm 17.01$ & $71.73 \pm 10.77$ & 0.561 \\
MSX2 & $21.34 \pm 7.49$ & $38.20 \pm 6.49$ & $<0.0001$ \\
FAM38A & $18.21 \pm 5.43$ & $32.92 \pm 6.71$ & $<0.0001$ \\
\hline
\end{tabular}

GC, gastric cancer.

tissues compared with the normal tissues. In the gastric cancer tissue, 2,016 sites (covering 1,008 genes) were hypermethylated and 629 sites (covering 344 genes) were hypomethylated (Table III). From the functional genome distribution standpoint, 824 sites (31\%) were located in promoters and 1,026 sites (39\%) are located in the gene body. In addition, 91 sites (3\%) and 704 sites (27\%) corresponded to the 3'-untranslated regions and intergenic sequences, respectively. From the $\mathrm{CpG}$ content and neighborhood context, $736 \mathrm{CpG}$ sites $(28 \%)$ were in $\mathrm{CpG}$ islands, 463 (17\%) were in CpG shores, 228 (9\%) were in
CpG shelves and 1,218 (46\%) were in the 'open sea' (isolated $\mathrm{CpGs}$ in the genome). The methylation differential sites were distributed among all 22 autosomal chromosomes and one sex chromosome. The majority of positions were harbored in chromosome one (9.1\%), followed by chromosomes two (8.9\%) and six $(7.7 \%)$. The distribution of these sites is shown in Figs. 1 and 2.

Gene regulation. A total of 979 genes were upregulated and 314 genes were downregulated in gastric cancer samples compared with the normal samples. Signaling pathway analyses showed that the majority of the genes that were upregulated and downregulated in gastric cancer were involved in the same pathways, including apoptosis, cell cycle, ErbB, Janus kinase-signal transducer and activator of transcription, mitogen-activated protein kinases, p53, transforming growth factor- $\beta$, Toll-like receptor, vascular endothelial growth factor and Wnt signaling pathways. We proposed that these pathway alterations may be associated with the clinical pathological features and outcome of GC patients. An integrated gene ontology database was used to annotate the molecular function of the differentially expressed genes. The results showed that genes that were upregulated and downregulated in gastric cancer were involved in the majority of the important biological process associated with human cancer, including regulation of the inhibitor- $\mathrm{\kappa B}$ kinase/nuclear factor- $\mathrm{\kappa B}$ 
cascade, cell differentiation, cell cycle arrest, caspase activation and cell proliferation (Table IV).

Methylation levels. In total, five differential sites (TRIM15, ITGAM, SLMO2, MSX2 and FAM38A) were selected and verified in 40 samples by pyrosequencing. The mean methylation levels of gastric cancer tissues were higher than those of normal gastric tissues for two sites (TRIM15 and ITGAM) and lower for two sites (MSX2 and FAM38A), which were consistent with the results of the microarray analysis. The mean methylation level of SLMO2 was not different between normal and cancer tissues (Table V, Fig. 3).

Transcriptional levels. To examine the transcriptional level of the four genes (TRIM15, IGTAM, MSX2 and FAM38A), qPCR was performed using primers specific for these genes. qPCR results showed that the expression levels of ITGAM, MSX2 and FAM38A were upregulated in gastric cancer tissues, while the expression level of TRIM15 was downregulated $(\mathrm{P}<0.05)$.

\section{Discussion}

DNA methylation is important in the development of gastric cancer. Previously, it has been found that hypermethylation inactivates a number of gene promoters. However, previous studies have been limited by technology that only allows analysis of a few genes. In addition, the majority of studies have paid close attention to the $\mathrm{CpG}$ island in the promoter region. According to current knowledge, only a few CpG dinucleotides have been identified at the promoter $\mathrm{CpG}$ islands, mostly scattered in the genome. In tumorigenesis, the importance of scattered $\mathrm{CpG}$ dinucleotide methylation remains poorly understood $(6,7)$. Therefore, understanding genome-wide DNA methylation changes is necessary for the in-depth investigation of tumor occurrence.

The latest generation of methylation microarrays includes the Infinium $450 \mathrm{~K}$ methylation microarray. This microarray detects $>450,000$ methylation sites per sample. It includes methylation regions, such as $\mathrm{CpG}$ islands, $\mathrm{CpG}$ shores, $\mathrm{CpG}$ sites outside of $\mathrm{CpG}$ islands, non-CpG methylated sites identified in human stem cells, differentially methylated sites identified in tumor versus normal tissues (multiple forms of cancer), across several tissue types, $\mathrm{CpG}$ islands outside of coding regions, miRNA promoter regions and disease-associated regions identified through genome-wide association study (8). To date, the Infinium $450 \mathrm{~K}$ methylation microarray is the most attractive, powerful and cost-effective tool available for generating quantitative DNA methylomes in healthy and diseased individuals $(9,10)$. Using the Infinium $450 \mathrm{~K}$ methylation microarray, the present study compared the genomic DNA methylation of gastric cancer with that of normal gastric tissue, screened 2,645 differential sites, showed the detailed distribution of these differential sites and established a gastric cancer DNA methylation profile. Verification of the microarray results by pyrosequencing showed that these results were reliable.

A considerable number of differentially methylated sites are located in the promoter region. However, the majority of them appear within the gene body. A number of previous studies have shown abnormal methylation of the $\mathrm{CpG}$ island in the promoter region and increasing attention has been paid to methylation of the gene body $(11,12)$. Unlike the correlation between promoter DNA methylation and gene transcription inhibition, the correlation between gene body methylation and gene expression is more complicated. A meta-analysis of this correlation by Jjingo et al (13) suggested that the gene body DNA methylation is highest when gene expression is moderate. Additionally, when gene expression is high or low, the degree of gene body DNA methylation is extremely low. In the current study of the correlation between methylation changes in four selected differentially methylated sites in the genome and gene expression, the effects of DNA methylation on gene expression varied between genes.

The current study found that the methylation changes in certain genes occurred in multiple sites, some in the promoter and some in the gene itself; certain sites became hypermethylated and others hypomethylated, which suggested that gene expression is regulated by complicated patterns of multi-site methylation. Bioinformatics analysis suggested no difference between genes with hypermethylated sites and genes with hypomethylated sites in associated signaling pathways, which included signaling pathways involved in apoptosis, cell proliferation and cell cycle control.

The present relatively large-scale investigation of methylation changes of gastric cancer, covering a relatively large genomic area, found a number of new differentially methylated sites, including hypermethylation and hypomethylation sites. Analysis of the results identified TRIM15, ITGAM, MSX2 and FAM38A as possible candidate sites clinically useful for the diagnosis and treatment of gastric cancer. In addition, a number of differentially methylated sites were identified in the microRNA gene. Further studies must be performed to explain this phenomenon.

\section{References}

1. Leung WK, Wu MS, Kakugawa Y, et al; Asia Pacific Working Group on Gastric Cancer: Screening for gastric cancer in Asia: current evidence and practice. Lancet Oncol 9: 279-287, 2008.

2. Brenner H, Rothenbacher D and Arndt V: Epidemiology of stomach cancer. Methods Mol Biol 472: 467-477, 2009.

3. Sapari NS, Loh M, Vaithilingam A and Soong R: Clinical potential of DNA methylation in gastric cancer: a meta-analysis. PLoS One 7: e36275, 2012.

4. Laird PW: Principles and challenges of genomewide DNA methylation analysis. Nat Rev Genet 11: 191-203, 2010.

5. Ku CS, Naidoo N, Wu M and Soong R: Studying the epigenome using next generation sequencing. J Med Genet 48: 721-730, 2011.

6. Shenker N and Flanagan JM: Intragenic DNA methylation: implication of this epigenetic mechanism for cancer research. $\mathrm{Br}$ J Cancer 106: 248-253, 2012.

7. Lister R, Pelizzola M, Dowen RH, et al: Human DNA methylomes at base resolution show widespread epigenomic differences. Nature 462: 315-322, 2009.

8. Sandoval J, Heyn HA, Moran S, et al: Validation of a DNA methylation microarray for $450,000 \mathrm{CpG}$ sites in the human genome. Epigenomics 6: 692-702, 2011.

9. Dedeurwaerder S, Defrance M, Calonne E, et al: Evaluation of the Infinium Methylation 450K technology. Epigenetics 3: 771-784, 2011.

10. Rakyan VK, Down TA, Balding DJ and Beck S: Epigenome-wide association studies for common human diseases. Nat Rev Genet 12: 529-541, 2011.

11. Maunakea AK, Nagarajan RP, Bilenky M, et al: Conserved role of intragenic DNA methylation in regulating alternative promoters. Nature 466: 253-257, 2010.

12. Ball MP, Li JB, Gao Y, et al: Targeted and genome-scale strategies reveal gene-body methylation signatures in human cells. Nat Biotechnol 27: 361-368, 2009.

13. Jjingo D, Conley AB, Yi S, et al: On the presence and role of human gene-body DNA methylation. Oncotarget 3: 462-474, 2012. 